\title{
PISMO DE DIFFERENTIIS I PLETHONA KRYTYKA ARYSTOTELESOWSKIEGO BOGA
}

\author{
De Differentiis and Pletho's Criticism of Aristotelian God
}

\author{
Magdalena Jaworska-Wołoszyn
}

DOI: 10.17846/CL.2019.12.1.90-101

\begin{abstract}
JAWORSKA-WOŁOSZYN, Magdalena. De Differentiis and Pletho's Criticism of Aristotelian God. The efforts of Byzantine scholars to show the differences between Hellenic thinkers are characteristic of the final phase of philosophy practiced in the Eastern Roman Empire. They are expressed is a conflict and an open dispute led by Plato's defender Georgios Gemistos and a supporter of Aristotle's doctrine, Scholarios. The dispute between these eminent and enlightened Byzantines was based on the question which of the Hellenic thinkers is better and whose doctrine is closer to the teaching of the Church. In the dispute between the Byzantines, one of the most important issues appeared to be the concept of God, hence the article will recall the arguments on the basis of which Georgios Gemistos in his writing of De Differentiis acknowledges Plato as the one who is worthy of greater validity and recognition.
\end{abstract}

Keywords: Plethon, De Differentiis, Plato, Aristotle, God

\begin{abstract}
Abstrakt: JAWORSKA-WOŁOSZYN, Magdalena. De Differentiis a Plethonova kritika aristotelovského Boha. Snahy byzantských bádatelov poukázat na rozdiely medzi helénskymi myslitelmi sú charakteristické pre záverečnú fázu filozofie Východorímskej ríše. Ich vyjadrením je konflikt a otvorená polemika medzi Georgiosom Gemistosom, obhajcom Platóna, a Scholariosom, podporovatelom aristotelovských doktrín. Dišputa medzi týmito uznávanými a vzdelanými Byzantíncami sa dotýkala otázky, ktorý z helénskych myslitelov je bližšie k pravde a koho doktrína je bližšia učeniu Cirkvi. Kedže jednou z klúčových otázok v dišpute bola koncepcia Boha, štúdia sa venuje argumentom, na základe ktorých Georgios Gemistos v jeho diele De Differentiis uznáva Platóna ako presvedčivejšieho a hodného vyššieho uznania.
\end{abstract}

Klúčové slová: Plethon, De Differentiis, Platón, Aristoteles, Boh

W końcowej fazie antyku i na początku wieków średnich spośród wszystkich szkół i nurtów powstałych w klasycznej i hellenistycznej Grecji przetrwały zwłaszcza dwa, tj. arystotelizm i platonizm ${ }^{1}$. Wpływ epikureizmu, stoicyzmu, cynizmu czy sceptycyzmu był znacznie słabszy, a reprezentowana przez owe nurty myśl dla bizantyjskich uczonych nie jawiła się równie żywo i atrakcyjnie. Niewątpliwie Arystoteles i Platon są tymi z grona antycznych myślicieli, którzy odegrali nadrzędną rolę w bizantyjskiej filozofii i których wpływ na jej kształtowanie był największy.

Por.: Early Byzantine Philosophy (Ierodiakonu, Zografidis 2010, 853-854); Le monde byzantin et la philosophie grecque (Brisson 1997, 751-753). 
By przeciwstawić się ascezie i praktyce wyrzeczeń popieranym przez świat chrześcijański, neoplatończycy rozwinęli system, w którym Platońska filozofia stała się synonimem mającej za ostateczny cel asymilację z Bogiem teologii. Wykazywano przeto jej zgodność z wszelkimi innymi teologiami, w tym pogańską i grecką. Arystotelizm z kolei, za pośrednictwem logiki i fizyki, stał się źródłem narzędzi, które umożliwiały tudzież otwierały drogę do teologii Platona. Bizantyjczycy nie zawsze jednak byli zainteresowani dokładnym i ścisłym odtwarzaniem doktryn głoszonych przez wielkich helleńskich filozofów. Znając Platońskie dialogi i pisma Stagiryty, sięgali również po wcześniejsze interpretacje i wykładnie ich myśli. Platona ujmowano poprzez pryzmat Plotyna, Jamblicha i Proklosa, a Arystotelesa głównie poprzez pryzmat Isagogi Porfiriusza.

Ponadto Bizantyjczycy wobec poglądów głoszonych przez Platona i Arystotelesa zajmowali różne postawy. Niektóre z nich, jako zgodne z chrześcijaństwem, przyjmowali, inne zaś odrzucali. W przeciwieństwie do krytykowanych elementów Platońskiej doktryny, tj. teorii idei oraz preegzystencji duszy, koncepcja Demiurga - twórcy świata oraz nieśmiertelności duszy spotkały się z aprobatą. Z drugiej strony Bizantyjczycy za przydatną mieli Arystotelesowską logikę i fizykę, przez co w wyjaśnianiu wielu kwestii odnośnie do natury boskiej sięgali po sylogistykę. Do opinii Arystotelesa ocenianych negatywnie należały znowuż m.in. wieczność świata, negacja życia pozagrobowego, koncepcja duszy i tzw. piątego elementu.

W nawiązaniu do głównych doktryn wyznaczających kierunki filozofii w Bizancjum, nie sposób traktować o jej rozwoju w kontekście konfliktu platoników i arystotelików. Co prawda wiek XV niesie za sobą przeciwstawianie Platona i Arystotelesa, ale wcześniej nie mamy do czynienia w Bizancjum z dążeniami jednoznacznie wykazującymi różnice między helleńskimi myślicielami. Działania te trzeba natomiast uznać za charakterystyczne dla końcowej fazy bizantyjskiej filozofii. Ich wyrazem jest konflikt i otwarta walka prowadzona przez obrońcę Platona - Georgiosa Gemistosa i zwolennika Arystotelesowskiej doktryny - Scholariosa. Spór między tymi wybitnymi i światłymi Bizantyjczykami tyczył się tego, który z Hellenów jest lepszy i która z proponowanych przezeń doktryn bliższa jest nauce Kościoła. Wśród licznych przywołanych i analizowanych przez Plethona i Georgiosa Scholariosa w dyspucie kwestii jedną z istotnych jawiła się koncepcja Boga. Odwołując się więc do Platońskich i Arystotelesowskich rozwiązań w tej materii, postaramy się wyjaśnić, dlaczego według Georgiosa Gemistosa pierwszy z helleńskich miłośników mądrości w piśmie De Differentiis jest godzien większego uznania i atencji.

\section{Chronologia i cele De Differentiis}

Pismo Georgiosa Gemistosa O różnicach między Platonem i Arystotelesem jest jedną $\mathrm{z}$ najważniejszych rozpraw, jakie powstały podczas pobytu bizantyjskiego myśliciela w Italii ${ }^{2}$. De Differentiis to jej uproszczony łaciński tytuł, pod którym stała się bardziej rozpoznawalna i znana. Ogólnie przyjmuje się, że dzieło Georgiosa Gemistosa powstało w 1439 roku $^{3}$. Warto też dodać, że stanowi ono podsumowanie i streszczenie treści jego wykładów prowadzonych dla włoskich humanistów we Florencji.

2 W Contra Scholarii Plethon wzmiankuje, że napisał traktat De Differentiis, kiedy był dotknięty chorobą i znudzony przebywał w domu we Florencji. Por.: Contra Scholarii 24 (Plethon 1988).

3 Na temat chronologii i kontekstu powstania De Differentiis zob. m.in.: George Gemistos Plethon. The Last of the Hellenes (Woodhouse 1986, 156; 177); Plato in the Italian Rennaissance (Hankins 1991, 205); Z Konstantynopola do Florencji, czyli odzyskiwanie greki na Zachodzie (Wesoly 1998, 291); Plethon and Scholarios on Aristotle (Karamanolis 2002, 253); Zapomniany filozof: Georgios Gemistos (Plethon). Zarys życia i twórczości (Jaworska 2008, 47); Pletho's Criticism of Aristotle’s Virtues: A Note on „De Differentiis” 12 (Fink 2011, 483); Filozofia bizantyńska (Tatakis 2012, 233); Posłowie (Wesoły 2012, 293-294). 
Pierwsza edycja De Differentiis przypada na rok 1540, kiedy to pismo Plethona ukazało się drukiem w Wenecji za sprawą Bernardusa Donatusa. Autorem pierwszego, lecz niewydanego tłumaczenia rozprawy na język łaciński był zmarły w 1542 roku Nikolaus Tridentinus Scuttellius. Następny przekład na łacinę pisma Plethona autorstwa George’a Chariandera został opublikowany w Bazylei w 1574 roku. Należy podkreślić, że wersja De Differentiis Donatusa ukazała się także w 1858 roku w Paryżu jako dodatek do edycji innego dzieła Georgiosa Gemistosa, czyli Traité des Lois pod redakcją Charles'a Alexandre'a. Jego przedruk wydano potem w Amsterdamie w 1966 roku. W 1866 roku natomiast, teksty Donatusa i Chariandera opublikował w Paryżu w swojej Patrologia Graeca Jacques Paul Migne. Wskutek odnalezienia autografu Plethona przez Roberta i François’a Masai wśród pism przekazanych Bibliotece św. Marka w Wenecji przez kardynała Bessariona wspomniane powyżej wydania De Differentiis w 1973 roku zastąpił opublikowany na łamach międzynarodowego czasopisma „Byzantion” tekst Bernadette Lagarde ${ }^{4}$. Jej bazujący na oryginalnym manuskrypcie greckim przekład rozprawy Bizantyjczyka na język francuski został przedłożony w Paryżu w postaci dysertacji doktorskiej w 1976 roku. W oparciu o ten sam manuskrypt ukazały się też kolejne tłumaczenia De Differentiis na język angielski i włoski. Autorem pierwszego z nich i pochodzącego z 1986 roku jest Christopher Montague Woodhouse, drugiego, z 2001 roku - Moreno Neri. W międzyczasie, w 1988 roku, pojawił się także przekład na język niemiecki Wilhelma Bluma.

De Differentiis to przełomowe dzieło w twórczości piśmienniczej bizantyjskiego filozofa. Jest to pierwsza rozprawa Bizantyjczyka, która nie została wydana pod nazwiskiem Georgiosa Gemistosa, lecz Plethona - przyjętym przez niego przydomkiem z uwagi na estymę żywioną wobec Platona. Jak słusznie zauważa George Karamanolis, i przed napisaniem De Differentiis Plethon poruszał w swoich pismach kwestie natury filozoficznej ${ }^{5}$, o czym świadczą jego inne prace, w szczególności zaś krótki traktat De virtutibus, który przypuszczalnie został wydany nieco wcześniej. De Differentiis mimo, że brakuje w nim pogańskich treści obecnych choćby w Streszczeniu nauk Zoroastra i Platona oraz Prawach, odzwierciedla jednak niespotykane jak dotąd u myśliciela wielkie zaangażowanie w sprawy filozofii. Sam tytuł tego pisma wyraźnie sugeruje przedmiot rozważań autora oraz jego intencje.

Celem Plethona w De Differentiis jest nakreślenie kluczowych różnic między Platonem a Arystotelesem. Myśliciel konsekwentnie realizuje swój zamysł, ale robi to w dość specyficzny sposób. Nie zmierza on bowiem do porównania doktryn obydwu helleńskich filozofów, a raczej wykazania niezgodności Arystotelesa z Platonem przy założeniu, że nauka tego ostatniego stanowi źródło jedynej prawdy. Okazuje się, że Stagiryta we wszystkich podstawowych, aczkolwiek ważnych filozoficznie zagadnieniach nie zgadzał się z opinią swojego mistrza. Według Bizantyjczyka nie pojął nawet głoszonej przez niego nauki. Postawa Plethona w De Differentiis jest nader krytyczna i różna od tej przyjętej w Prawach, gdzie Bizantyjczyk docenia właściwą dlań naturalną filozofię ${ }^{6}$. W prologu ostatniego ze swoich dzieł podaje, że jego książka zawiera m.in. fizykę podług Arystotelesa, w De Differentiis zaś przeprowadzona przez niego analiza poglądów Hellena wykazuje nieprawidłowości i błędy niemal w każdej badanej dziedzinie. Krytyce zostają poddane nie tylko Arystotelesowska logika, metafizyka, psychologia, ale i wątki natury etycznej, kosmologicznej, nie wspominając już teorii o ideach, której poświęcił najwięcej uwagi i miejsca.

\footnotetext{
Por.: Le "De differentiis" de Pléthon d'après l’autographe de la Marcienne (Lagarde 1973, 321-343).

Por.: Plethon and Scholarios on Aristotle (Karamanolis 2002, 260).

6 Por.: Plethona Zapis praw (Wesoły - Jaworska-Wołoszyn 2014, 306). Skądinąd w innym piśmie, tj. w Contra Scholarii Plethon wzmiankuje, że nie lekceważy osiągnięć Stagiryty na polu nauk przyrodniczych, wręcz przeciwnie, zachęca innych do ich studiowania. Dodaje jednak, że nie należy czcić i uznawać wszystkiego, co napisał, zwłaszcza popełnionych przezeń omyłek i błędów.
} 
Nie bez znaczenia tutaj pozostaje sam język i ton wypowiedzi Plethona, który nierzadko jawi się jako nazbyt ofensywny, a czasem wręcz obraźliwy.

Ocena doktryny Arystotelesa w De Differentiis jest w pełni negatywna. Wyjaśnienia tego stanu rzeczy dają nam jednak już pierwsze słowa Plethona rozpoczynające jego polemiczne dzieło. Filozof konstatuje, że wbrew opinii większości ludzi (zwłaszcza na Zachodzie) pozostających pod wpływem Awerroesa i dzisiaj ceniących bardziej Arystotelesa od Platona, Hellenowie i Rzymianie niegdyś darzyli większym szacunkiem Platona. Tylko ci zatem, którzy doceniają Platona, mogą pozostać wierni swoim przodkom i ich naukom. Powiązanie i utożsamienie przez Plethona zwolenników Platońskiej nauki z antyczną filozofią ma skądinąd na celu rzeczywistą dysocjację dwóch sprzecznych ze sobą tradycji - helleńsko-bizantyjskiej i świata Zachodu. Co więcej, ma też wykazać, że to Platon i głoszona przezeń doktryna bliższe są kościelnym dogmatom i chrześcijańskiej teologii, niż Arystoteles i jego przekonania, jak to zwykli uznawać zachodni uczeni. Warto przypomnieć, że wiedza Włochów o Platonie owego czasu zazwyczaj ograniczała się do znajomości nielicznych dialogów, które zostały przetłumaczone na łacinę, przez co rozległa erudycja Plethona musiała wzbudzać ich zainteresowanie i podziw. Przekonanie Bizantyjczyka, że łacinnicy niewiele wiedzą o Platońskiej doktrynie naturalnie wynikało z faktu, że przez długi okres w przekładach osiągalne dlań były tylko trzy spośród wszystkich dialogów helleńskiego myśliciela. Mowa jest o Timajosie, którego od IV wieku kosmologiczną opowieść powszechnie uznawano za zgodną z biblijną Genesis, oraz o dostępnych od XII wieku Fedonie i Menonie, których niektóre wątki odbierano za heretyckie. Sytuacji nie zmieniły znacząco kolejne tłumaczenia niektórych Platońskich pism Leonarda Bruniego. Pogląd Plethona był tym bardziej uzasadniony, że losy Arystotelesa na Zachodzie przedstawiały się zgoła odmiennie. Począwszy od końca XIII w tłumaczeniu na język łaciński osiągalny był zbiór wszystkich jego prac. Stąd też jedną z intencji myśliciela w De Differentiis, obok udowodnienia wyższości Platona nad Arystotelesem tudzież większej zgodności jego filozofii z chrześcijańską wiarą, było zniwelowanie luk i błędów w zachodnim rozumieniu nauk głoszonych przez obojga Greków. Dla Plethona humaniści nie mieli wystarczających informacji na temat Platona, a wskutek arabskich i scholastycznych interpretacji (m.in. Awerroesa, Awicenny i św. Tomasza) posiadali zniekształcone i błędne opinie o doktrynie jego następcy i ucznia ${ }^{7}$. Ostatecznie nic w tym zadziwiającego, że w De Differentiis Bizantyjczyk sięga po przeciwstawienie doktryn wielkich myślicieli Hellady, aby uświadomić włoskich humanistów, czyli tych, dla których spisał swoje wykłady, że pierwsza z nich, stanowiąc jedyne uznawane od wieków źródło prawdy, jest dobra, a druga, będąc nie do zaakceptowania - zła.

\section{De Differentiis i jego rola w XV-wiecznej kontrowersji wokół Platona i Arystotelesa}

W XIV-wiecznym sporze hezychastycznym, którego głównymi przedstawicielami byli zwolennik hezychazmu Grzegorz Palamas i jego adwersarz - Barlaam z Kalabrii, wyłoniły się ważne przeciwieństwa między dwoma największymi autorytetami Hellady, tj. Platonem i Arystotelesem. Te zarysowane podówczas różnice nie miały intensywnej natury i nie wytworzyły szczególnego napięcia w gronie bizantyjskich uczonych. Za sprawą przeciwników Palamasa i jego sympatyków zostały jednak postawione nader ważne pytania, mianowicie - który z helleńskich myślicieli jest większy i który z nich jest bliższy chrześcijańskiej wierze? W wieku XV, na który przypada ostatnia i bodaj największa ze wszystkich kontrowersji powstałych w łonie bizantyjskiej filozofii, podjęte

Por.: Byzantská filozofia (Zozulak 2016, 168). 
w poprzedzającym stuleciu kwestie stały się przedmiotem żywej filozoficznej dyskusji ${ }^{8}$. Jej początek wyznacza rok 1439. Wtedy to właśnie Plethon wydał swoją krótką rozprawę o wymownym tytule De Differentiis, w której ostro skrytykował doktrynę Arystotelesa.

Dzieło Bizantyjczyka wywołało trwający ponad 30 lat spór, którego nie była w stanie powstrzymać ani śmierć filozofa, ani upadek stolicy Cesarstwa Wschodniorzymskiego. Co istotne, kontrowersja wokół Platona i Arystotelesa wpierw zaangażowała wielu najwybitniejszych uczonych ginącego Bizancjum, a następnie stała się źródłem inspiracji dla reprezentantów włoskiego humanizmu. Pierwszym, który zareagował na pamflet Plethona i wystąpił w obronie Stagiryty, był Jerzy Scholarios. Swojemu krytycznemu stanowisku wobec poglądów Plethona dał wyraz w (powstałej w drugiej połowie 1443 roku lub pierwszej połowie roku 1444) replice pt. Przeciw wątpliwościom Plethona co do Arystotelesa. Powszechnie znana jest ona pod tytułem Contra Plethonem. Na zawarte w niej zarzuty Plethon odpowiedział około 1448/9 roku w piśmie Contra Scholarii, gdzie poparł swoją argumentację bardziej naukowym wywodem. Nie doczekało się ono bezpośredniej reakcji ze strony Scholariosa, albowiem ten, straciwszy zainteresowanie problemem, około 1450 roku napisał do niego utrzymany w pojednawczym tonie list. Zainicjowana przez Plethona i Scholariosa debata o wielkich myślicielach Hellady toczyła się nieprzerwanie przez lata i była dalej kontynuowana przez Mateusza Kamariotesa, Teodora Gazesa, Michała Apostolisa, Andronikosa Kallistosa, Jerzego z Trapezuntu oraz Bessariona. De Differentiis jest zatem nie tylko jednym z przełomowych pism w życiu samego Plethona, ale i w finalnej fazie bizantyjskiej filozofii. Polemiczne dzieło myśliciela ożywiło bizantyjską myśl filozoficzną. Stało się dla innych Bizantyjczyków źródłem inspiracji do tworzenia nowych pism, podejmowania kluczowych dla filozofii kwestii, nade wszystko zaś - określenia właściwego im stosunku do antycznej tradycji. $\mathrm{Z}$ drugiej strony, za równie nieoceniony należy mieć wpływ De Differentiis i jego autora na kulturę i filozofię świata łacińskiego. Za sprawą działalności Plethona we Florencji niesłychanie przecież wzrosło w Italii zainteresowanie nieznanym tam wtedy Platonem i głoszoną przezeń doktryną. Dzięki Plethonowi zdominowany przez wieki przez Arystotelesa Zachód zyskał nowe szanse i możliwości, czyli odkrycie platonizmu. Przywrócenie Platona skłoniło Cosimo de’ Medici do założenia w 1462 roku Akademii Platońskiej we Florencji. Dzięki związanemu z nią Marsilio Ficino po raz pierwszy dokonano także całościowego przekładu Platońskich pism.

\section{Arystotelesowski Bóg w ujęciu De Differentiis}

W De Differentiis Plethon swoją krytykę poszczególnych składowych doktryny Arystotelesa rozpoczyna od właściwego dlań ujęcia Boga. Jest dalece prawdopodobne, że według Bizantyjczyka Arystotelesowska koncepcja Istoty Najwyższej jako jawnie niezgodna z chrześcijańską wykładnią stanowi doskonały punkt wyjścia dla zamierzonego ataku, którego celem jest wykazanie kolejnych ogólnych nieprawidłowości w rozumowaniu Hellena.

Już w pierwszych słowach Plethon zauważa, że w pismach Stagiryty brakuje wypowiedzi o Bogu, z których można by wywnioskować, iż jest on stwórcą świata, a wręcz przeciwnie, można z nich wyczytać, że nie jest on kreatorem czegokolwiek. Czyniąc aluzję do Metafizyki i Fizyki ${ }^{9}$

8 Szerzej na temat kontrowersji wokół Platona i Arystotelesa oraz uczestników tego sporu w: George of Trebizond (Monfasani 1976, 201-229); Plato in the Italian Rennaissance (Hankins 1991, 193-217); Radical Platonism in Byzantium. Illumination and Utopia in Gemistos Plethon (Siniossoglou 2011, 408417); Z Konstantynopola do Florencji, czyli odzyskiwanie greki na Zachodzie (Wesoły 1998, 290-297); Posłowie (Wesoły 2012, 293-296); Zarys historyczny filozofii bizantyjskiej i jej podstawowe zagadnienia (Viglas 2010, 130-132).

9 Por.: Metafizyka (Arystoteles 1983,1072b); Fizyka (Arystoteles 1968, 258b). 
stwierdza, że dla Arystotelesa Bóg jest tożsamy z siłą wprawiającą świat w ruch ${ }^{10}$. W tym samym paragrafie dalej podaje, że takie wyobrażenie Boga jest błędne. Co więcej stanowi przejaw czystej ignorancji, albowiem pomija i nie wychwala najwyższych Jego dokonań. Godnym samego Boga nie jest nawet utożsamienie Go z celem tudzież z ostatnią przyczyną. Jak głosi bowiem Stagiryta, Bóg jest celem zmiany i ruchu, a nie istoty i istnienia wszelakich rzeczy. Arystotelesowska Istota Najwyższa nie może zresztą pełnić funkcji tego, który tworzy, albowiem, jak donosi nam Plethon w Contra Scholarii ${ }^{11}$, słowo arché nie tylko oznacza pierwszą przyczynę, źródło, początek, lecz i autorytet, władzę i siłę. A jest oczywistym, że Arystoteles nie porównuje Boga do architekta, który tworzy dom, lecz do wodza tworzącego szeregi armii ${ }^{12}$. Ma on zatem na myśli autorytet w postaci siły rządzącej, która w żadnym przypadku nie jest źródłem bycia swych poddanych, a jedynie prawa i porządku. Ten zresztą, który uchodzi za siłę wprawiającą świat w ruch, bynajmniej nie musi być odpowiedzialny za stworzenie owego świata. Wszak inaczej można by mniemać, że skoro wół zapewnia wozowi ruch, to i tworzy wagon. Wiadomo jednak, że stwarzać ruch nie oznacza od razu samego tworzenia. Stąd odpowiednikiem tego, który tworzy w kontekście ruchu lub zmiany, jest ten, który bierze lub otrzymuje, a w kontekście stwarzania odpowiednikiem twórcy jest rzecz zrobiona lub stworzona ${ }^{13}$.

Niestosowność Arystotelesowskiego przedstawienia Boga jest tym bardziej rażąca dla Plethona, gdy zestawia je z Platońską opowieścią o powstaniu świata. W nawiązaniu do Timajosa Bizantyjczyk konstatuje, że Platon miał Boga i za władcę całego wszechświata i tego, dzięki któremu zawdzięcza on swe istnienie ${ }^{14}$. Ponadto, zdaniem Plethona, w przypadku Platońskiej nauki jasno mowa jest o tym, że Demiurg - twórca wszystkiego - pod względem ontologicznym wyróżnia się od pozostałych zasad świata, czyli jego składowych o charakterze materialnym i inteligibilnym (materii i idei). Ostatecznie myśliciel, konfrontując rozważania obu Hellenów o Istocie Najwyższej obecnych we wspomnianych dziełach, a precyzyjnie rzecz ujmując, w Timajosie oraz Metafizyce i Fizyce, nie ma jakichkolwiek wątpliwości co do tego, że Platońskie ujęcie Boga jest bardziej stosowne i właściwe. Z pierwszego przecież fragmentu De Differentiis dowiadujemy się również, że Arystoteles, nie mając Boga za stwórcę kosmosu i nie myśląc o Bogu w ten sposób, pozostaje w opozycji do najlepszej filozofii. Ta ostatnia zaś jest wspólna wszystkim ludziom posiadającym zdrowy rozsądek.

Na początku kolejnego z paragrafów traktatu Bizantyjczyk konstatuje, że Arystoteles nawet nie wierzy we wspomnianą powyżej doktrynę ${ }^{15}$. W jego pismach całkowicie brakuje odniesień do najlepszej z nauk. Pełno w nich natomiast rozległych wywodów na temat embrionów czy skorupiaków. Ten sam zarzut bizantyjski myśliciel wobec Hellena powtarza i identycznie objaśnia w Contra Scholarii. W piśmie tym stwierdza, że Arystoteles woli dręczyć ludzi niekończącymi się i nazbyt detalicznymi opowieściami na temat nasion, zarodków i skorupiaków, aniżeli wypowiadać się o najznamienitszej nauce, która powinna stanowić przewodni temat filozoficznych dociekań.

10 Por.: De Differentiis (Plethon 1986, 192, 3 (PG I, BL I, MN I). Woodhouse jako jedyny do tej pory podzielił De Differentiis na 56 paragrafów. Pierwsza liczba odnosi się do paginacji, druga zaś tyczy się wprowadzonego przezeń podziału tekstu na ustępy, do którego odwołujemy się w artykule. Pozostałe podziały ujęte w nawiasie odsyłają do układów numerycznych pisma Plethona zachowanych przez Migne, Lagarde i Neri.

11 Por.: Contra Scholarii (Plethonis 1886, PG 160, 991).

12 Por.: Metafizyka (Arystoteles 1983, 1075a).

13 Por.: Contra Scholarii (Plethonis 1886, PG 160, 1008).

14 Por.: Timajos (Platon 1999a, 27d-30d).

15 Por.: De Differentiis (Plethon 1986,193, 4 (PG I, BL I, MN I). 
Zgodnie też z podaniem Plethona nie przemilczał on po prostu aktu stworzenia, lecz użył zwrotów, które jawnie wskazują na to, że w niego w ogóle nie wierzy ${ }^{16}$.

Dla Plethona Arystoteles jawi się także jako krytyk tych, którzy przyjmują powstawanie wiecznych istot. Negując powstawanie tychże bytów, uznaje je za absurdalne i niemożliwe. Ponadto dla Hellena powstawanie w czasie stanowi konieczną konsekwencję powstawania przyczynowego ${ }^{17}$, mimo że już wcześniej Platon rozumiał to zgoła inaczej. O tym, że ten ostatni powyższą kwestię potraktował należycie, a przeto był właśnie świadom, że powstawanie w czasie nie stanowi koniecznej konsekwencji powstawania przyczynowego, dowodzą dwa ustępy z jego dialogów przywołane przez Plethona w niniejszym paragrafie. Mowa tutaj o Fajdrosie, gdzie duszę ujmuje się jako nieśmiertelną i niestworzoną w czasie oraz Timajosie, z którego pochodzi spostrzeżenie, że została ona stworzona przyczynowo, czyli przez Boga będącego jej zewnętrzną przyczyną ${ }^{18}$.

Podniesiony przez bizantyjskiego myśliciela problem w De Differentiis ulega szerszemu objaśnieniu w Contra Scholarii. W piśmie tym ponownie sygnalizuje, że Arystoteles nie był w stanie pojąć wprowadzonego przez swego mistrza rozróżnienia ${ }^{19}$. Gdyby bowiem zrozumiał różnicę, o jakiej wspominał Platon, to mógłby zakwestionować właściwy dlań pogląd w tych słowach: masz rację, mówiąc, że świat został stworzony przez Boga, lecz mylisz się, że został on stworzony w czasie, wcześniej nie istniejąc. Niestety Stagiryta nie zrobił tego. Zdaniem Plethona skrytykował Platona za to, że nie miał świata za wieczny, albowiem w zgodzie z jego własną teorią na temat wieczności mogłoby to zaprzeczyć kreacji świata przez Boga. Jednakowoż przywłaszczył sobie doktrynę wieczności świata. W rzeczywistości zaś, wbrew przekonaniu Stagiryty, Platon ujmował świat jako wieczny. Świadczą o tym wypowiedziane przezeń słowa w Timajosie, zgodnie z którymi czas powstał jednocześnie ze światem ${ }^{20}$ oraz, że stwórca był dobry i że w Nim, który jest dobrem, żadne zło nigdy nie powstało. Będąc też wyzbyty zła, pragnął, by wszystko w miarę możliwości było takim, jak on sam, czyli wiecznym ${ }^{21}$. To wszystko, o czym mowa lepiej wyraził więc Platon niż Arystoteles. Wypowiedź Bizantyjczyka w Contra Scholarii wieńczy naturalna konstatacja, że w rzeczy samej Stagiryta jawnie nie wierzy, że świat został stworzony przez Boga ${ }^{22}$. To samo stwierdzenie obecne jest w De Differentiis, ponieważ dla Plethona, jeżeli Arystoteles przypisuje światu wieczność, to z konieczności musi odrzucać i możliwość jego powstania, a w następstwie i tego, kto mógłby go stworzyć. Inaczej mówiąc, w obu swoich pismach wykazuje, że w przypadku Stagiryty nie sposób mówić o stwórcy świata, bo jest on dlań zbędny. W konsekwencji krytyka Arystotelesa nie pociąga za sobą zakwestionowania wieczności świata, ale tego, że nie został on przez Istotę Najwyższą stworzony.

W dalszej części wywodu Plethon traktuje już o innym absurdzie tkwiącym u podstaw Arystotelesowskiego rozumowania o Bogu. Wiąże się on z wyznaczaniem różnych sfer i stosownych dlań ruchów. Według Bizantyjczyka Stagiryta, przypisując sfery i ich ruch oddzielnym inteligencjom i substancjom, w ten sam sposób wyznacza pewną sferę i ruch samemu Bogu. To zaś prowadzi

16 Por.: Contra Scholarii (Plethonis 1886, PG 160,1012).

17 Por.: Metafizyka (Arystoteles 1983,1091a).

18 Por.: Fajdros (Platon 1999b, 246a); Timajos (Platon 1999a, 36e). Szerzej na temat argumentacji Plethona w: Georgius Gemistus Pletho's Criticism of Plato and Aristotle (Taylor 1921, 60). Warto dodać, że to samo rozumowanie obecne jest w innym piśmie Bizantyjczyka, czyli w Contra Scholarii (Plethonis 1886, PG 160, 987-8).

19 Por.: Contra Scholarii (Plethonis 1886, PG 160, 987). Jak słusznie zauważa G. Karamanolis, zdaniem Plethona nie należy literalnie odczytywać Platońskiego stworzenia wszechświata w czasie, o którym mowa w Timajosie.

20 Por.: Timajos (Platon 1999a, 38b).

21 Ibidem (29e).

22 Por.: Contra Scholarii (Plethonis 1886, PG 160, 988). 
do usytuowania Istoty Najwyższej na poziomie inteligencji odeń zależnych, co stanowi dla Niej ujmę i pomniejsza Jej godnośćc ${ }^{3}$. Dla Plethona potwierdzeniem tego nonsensownego stanu rzeczy jest skądinąd rozumowanie właściwe rozważaniom greckiego myśliciela na temat sprawiedliwości. Stagiryta uznaje bowiem, że sprawiedliwy udział implikuje konieczność proporcjonalności rzeczy przypisanych w stosunku do tych, do których są przypisane ${ }^{24}$. Tak więc wszelakie sfery, jedne wraz z drugimi, są z tej samej substancji, wszystkie też mają niezniszczalne ciała, a ich ruch - jak i one same - jest wieczny. Stąd i potrzeba, by wszystkie owe oddzielne inteligencje, którym to zostały przydzielone sfery, jedne i drugie były z tej samej substancji, i by żadna z nich nie była traktowana jako różna od pozostałych. Ostatecznie pierwsza z nich w stosunku do pozostałych może być wyższą tylko w tej mierze, w jakiej przydana jej sfera może za takową uchodzić w stosunku do innych sfer. Taki jednak stopień wyższości jest niewystarczający dla Boga, co zresztą dostrzegają liczni, nawet ci o małym rozumie i nieutalentowani. Zgodnie z podaniem Bizantyjczyka sam mniej lub bardziej wierny Arystotelesowi Arab Awicenna uznał tę jego naukę za niedorzeczną. I choć przypisał gwiazdy i sfery innym oddzielnym umysłom, to nie śmiał przypisać jakiejkolwiek czy to gwiazdy, czy sfery Istocie Najwyższej. W odróżnieniu do Stagiryty był przeto świadom, że Bóg zajmuje wśród bytów najwyższą pozycję i że miejsce przynależne Bogu znajduje się ponad wszystkim.

Ostatni z przywołanych przez Plethona zarzutów w De Differentiis stanowi czystą aluzję do Arystotelesowskiego wywodu o Bogu mającego miejsce w 12 księdze Metafizyki. Nieruchomy Poruszyciel jest dlań boską zasadą, która na wzór pozostałych niebieskich sfer stanowi poruszający się wiecznie i niepodlegający zniszczeniu intelekt. To zaś sprawia, że u Arystotelesa Bóg pod względem istoty nie różni się w zasadzie niczym od innych wiecznych bytów, a to $\mathrm{z}$ tej racji, że jest jedynie dowódcą wojska. Wydaje się także, że bizantyjski filozof kwestionuje prymat i nadrzędność Boga jako wodza w stosunku do innych członków armii nie dostrzegając przy tym, że w rzeczywistości Arystotelesowska Istota Najwyższa ani niej jest sferą, ani też nie jest zależna od poruszających się sfer. Co więcej, odrzuca postulowany w tej księdze Metafizyki porządek tudzież hierarchię substancji wprawiających w ruch sfery niebieskie ${ }^{25}$. Ostatecznie dla Plethona Arystotelesowski Bóg jest tylko przyczyną ruchu, o czym myśliciel wspomina także w Contra Scholarii, gdy twierdzi, że jest to następstwo przyjęcia przez Hellena szeregu podporządkowanych bogów równego ruchom sfer niebieskich ${ }^{26}$. Stamtąd też i pochodzi konstatacja: Arystoteles w przypisaniu niebu możliwości wiecznego istnienia zakłada, że jest ono niestworzone i nieśmiertelne, stąd właściwym dla niego jest przekonanie, że niebo nie zostało stworzone przez żadnego stwórcę. I jeszcze inna: Stagiryta nazwał Boga przyczyną, a nawet Pierwszą Przyczyną, ale jedną wśród wielu. Ten język nie jest właściwy Bogu, który jest królem wszystkiego lub, jak Platon i Zoroaster utrzymywali, musi być jedynym, a nie jednym wśród wielu innych bóstw ${ }^{27}$. Arystoteles wierzy w Boga jedynie jako w przyczynę ruchu nieba, lecz nie jego istotnego bycia ${ }^{28}$. Przedstawienie Boga na równi z innymi substancjami i w tym więc przypadku implikuje, iż nie jest On stwórcą czegokolwiek tudzież celem istoty i istnienia wszelakich rzeczy.

\footnotetext{
23 Por.: Metafizyka (Arystoteles 1983,1072a).

24 Por.: Etyka nikomachejska (Arystoteles 1982,V, 1131a).

25 Por:: Metafizyka (Arystoteles 1983,1073b).

26 Por.: Contra Scholarii (Plethonis 1886, PG 160, 986); Metafizyka (Arystoteles 1983,1074a).

27 Por.: Contra Scholarii (Plethonis 1886, PG 160, 1010).

28 Por.: Contra Scholarii (Plethonis 1886, PG 160, 1010).
} 


\section{Konkluzje}

W piśmie De Differentiis, które rozpoczyna się od rozważań Plethona na temat Arystotelesowskiego Boga $\mathrm{w}$ pełni brakuje wypowiedzi o pozytywnym, nawet tych o neutralnym charakterze. W świetle dzieła wszelakie uwagi Stagiryty w kwestii Istoty Najwyższej jawią się jako złe i omylne. Arystotelesowki Bóg nie tylko nie jest tutaj stwórcą wszechświata i znajdujących się w nim bytów, ale nawet nie wyróżnia się niczym szczególnym w stosunku do pozostałych substancji, którym dana jest ta sama wieczna i niezniszczalna natura. Bóg w rozumieniu Hellena zostaje odarty z należytego Mu szacunku, dostojeństwa i godności. Nie dziwi więc, że autor De Differentiis uznaje poglądy Arystotelesa za czysty przejaw ignorancji i niezrozumienia omawianej materii, i że ten ostatni nie ma żadnych szans, by w dyskusji o Bogu konkurować ze swoim mistrzem.

Z drugiej strony krytyczna postawa Plethona względem Arystotelesowskiego Boga zapewne jest zbieżna z tą, która była właściwa i innym platonikom. Dlatego też w piśmie Bizantyjczyka odnajdujemy przekonanie, że filozofia Platona jest wyższą, nade wszystko zaś objawioną ludzkości jedyną dobrą i prawdziwą doktryną, o czym już wcześniej m.in. wspominał Diogenes Laertios ${ }^{29}$. Przedstawiona w De Differentiis krytyka Boga (podobnie jak i dalszych odrzuconych przez Plethona elementów nauki Hellena) ma ostatecznie wykazać, że głoszona przezeń filozofia jest niezgodna z chrześcijańską doktryną i że Arystoteles, w odróżnieniu do Platona, przejawiał skłonności do ateizmu. Istotnie w Contra Scholarii myśliciel podaje, że choć nigdy nie porównywał Stagiryty do niewierzącego, to jednak wypowiedzi o Bogu obecne w jego pismach stanowią dlań świadectwo inklinacji do niewiary w istnienie Istoty Najwyższej ${ }^{30}$. W Contra Scholarii stan rzeczy, o którym mowa, potwierdzają co najmniej cztery z użytych przez Bizantyjczyka argumentów. Po pierwsze, Arystoteles nie przedstawił Boga jako lidera wśród bogów, wyjątkowego w swej boskości, niczym Platon i Zoroaster, wręcz przeciwnie, ze wszystkich bóstw uczynił równych sobie partnerów. Po drugie, ani Boga, ani innych bogów nie miał on za twórców świata, jak uznają wszyscy filozofowie i większość laików. Po trzecie, nie przyjął żadnego boskiego umysłu kierującego rzeczami w naturze na wzór większości z obawiających się Boga ludzi. I co równie ważne, zakwestionował znaczenie przeznaczenia i boskiej opatrzności w sprawach czysto ludzkich ${ }^{31}$.

Bez wątpienia bizantyjski filozof, poprzez obnażenie nieprawidłowości tkwiących u podstaw rozumowania Arystotelesa o Bogu w De Differentiis i Contra Scholarii, chciał przekonać zachodnich uczonych, jak dalece ich opinie wypaczone przez tradycję arabską i scholastyczną są mylne w tej materii. Biorąc pod uwagę dydaktyczno-objaśniający charakter i wymowę De Differentiis trudno przyjąć, że dzieło Plethona miało dla niego znaczenie, jakie nadaje mu Darien C. DeBolt. Badacz ten, w wykładach prowadzonych przez myśliciela we Florencji na użytek włoskich humanistów, upatruje możliwość na stworzenie przezeń gruntu do propagowania czy rozpowszechniania ezoterycznych i pogańskich treści (DeBolt 2018). Te jednak właściwe są dla ostatnich prac Plethona, mianowicie dla Zapisu praw oraz Streszczenia nauk Zoroastra i Platona - pracy stanowiącej krótkie podsumowanie myśli zawartych w największym dziele. De Differentiis, poprzez wskazanie różnic między Platonem i Arystotelesem, służyło raczej skorygowaniu rozumienia ich doktryn na Zachodzie i wpojeniu włoskim badaczom, że pierwszy z Hellenów zasługuje na większą atencję, albowiem właściwa dlań nauka jest bardziej zgodna z chrześcijańskimi dogmatami, niż przynależąca do człowieka o ateistycznych skłonnościach - tak uwielbianego w świecie zachodnim - jego następcy i ucznia.

29 Por.: Żywoty i poglądy stynnych filozofów (Diogenes Laertios 1984, III, 56).

30 Por.: Contra Scholarii (Plethonis 1886, PG 160, 1005).

31 Por.: Contra Scholarii (Plethonis 1886, PG 160, 1005). 
Pomijając postawione przez autora De Differentiis cele należy dodać, że właściwa dlań interpretacja Arystotelesowskiego Boga jest niezgodna ze współczesnymi. W świetle najnowszych ustaleń w swojej Metafizyce Stagiryta nie docieka bowiem takich dziedzin jak teologia czy ontologia, lecz raczej teorii pryncypiów, a więc pierwszych zasad i przyczyn ${ }^{32}$. Bizantyjczyk w piśmie De Differentiis chętnie sięga po passusy dotyczące Istoty Najwyższej obecne w księdze Lambda Arystotelesowskiej Metafizyki, ta zaś w pierwszej połowie traktuje o zasadach substancji ziemskich o charakterze zmysłowym, w drugiej zaś - o zasadach substancji wiecznych ruchomych i nieruchomych ujętych jako ich czynniki sprawcze. Tam też, jak słusznie zauważa Marian Wesoły, nieporuszony poruszyciel ,jest pierwszym z wielu (54 lub 55) czynników sprawczych w sferach koncentrycznych niebios dla wyjaśnienia ruchu planet (Wesoły 2017, 455)”. Ponadto księga Lambda, stanowiąc uzupełnienie dociekań nad pierwszymi przyczynami substancji, w części poświęconej zasadom substancji wiecznych i nieruchomych (czyli będącym dla Greków boskim planetom i gwiazdom), nie stanowi wykładu z zakresu teologii, lecz element wiedzy na temat pierwszych przyczyn. To zaś oznacza, że Plethon podąża za mylnym ujęciem metafizyki Arystotelesa, biorącym swe źródło w teologizującej interpretacji autorstwa Aleksandra z Afrodyzji, która wywarła niemały wpływ na jej dalsze późnoantyczne, bizantyjskie, arabskie, scholastyczne, a nawet współczesne przeinaczone wykładnie. W sprowadzeniu Arystotelesowskiej filozofii pierwszej do teologii przez bizantyjskiego myśliciela można zatem dostrzec omyłkę, która ostatecznie prowadzi do wniosku, że tak naprawdę przedmiotem jego krytyki nie była Istota Najwyższa, a jedynie nieporuszony poruszyciel pojęty jako zwyczajna przyczyna sprawcza ruchu planet i motor niebios. Reasumując, skoro „oryginalna metafizyka Arystotelesa nie była ani ontologią, ani teologią, tracą na mocy tradycyjnie nadawane jej w tym względzie interpretacje oraz stawiane przy tym zarzuty (Wesoły 2017,442$)$."

\section{REFERENCES}

Aristotele. 2017. La Metafisica. Trans. by E. Berti. Roma-Bari.

Arystoteles. 1968. Fizyka. Trans. by K. Leśniak. Warszawa.

Arystoteles. 1982. Etyka nikomachejska. Trans. by D. Gromska. Warszawa.

Arystoteles. 1983. Metafizyka. Trans. by K. Leśniak. Warszawa.

Brisson, Luc. 1997. Le monde byzantin et la philosophie grecque. In Canto-Sperber, Monique (ed.). Philosophie grecque. Paris, 745-779.

Bydén, Börje. 2013. ,No prince of perfection': Byzantine Anti-Aristotelianism from the patristic period to Pletho. In Angelov, Dimiter, Saxby Michael (eds.). Power and Subversion in Byzantium: Papers from the 43rd Spring Symposium of Byzantine Studies. University of Birmingham, March 2010. Farnham, 147-176.

DeBolt, Darien C. 2018. Georgios Gemistos Plethon on God: Heterodoxy in Defense of Orthodoxy. https://www.bu.edu/wcp/Papers/Medi/MediDebo.htm.

Fink, Jakob Leth. 2011. Pletho's Criticism of Aristotle's Virtues: A Note on „De Differentiis” 12. In Greek, Roman, and Byzantine Studies 51, 483-497.

Hankins, James. 1991. Plato in the Italian Rennaissance. Vol I-II. Leiden-New York. Ierodiakonou, Katerina, Zografidis George. 2010. Early Byzantine Philosophy. In Gerson, Lloyd P. (ed.). The Cambridge History of Philosophy in Late Antiquity. vol. II. Cambridge, 843-868.

32 Por.: La Metafisica (Aristotele 2017); Wokót najnowszych badań nad „Metafizyką” Arystotelesa (Wesoły 2017, 442). 
Jaworska, Magdalena. 2008. Zapomniany filozof: Georgios Gemistos (Plethon). Zarys życia i twórczości. Gorzów Wielkopolski.

Karamanolis, George. 2002. Plethon and Scholarios on Aristotle. In Ierodiakonou, Katerina (ed.). Byzantine Philosophy and its Ancient Sources. Oxford, 253-282.

Laertios Diogenes. 1984. Żywoty i poglądy słynnych filozofów. Trans. by I. Krońska. Warszawa.

Lagarde, Bernadette. 1973. Le „De differentiis” de Pléthon d'après l'autographe de la Marcienne. In Byzantion XLIII, 321-343.

Monfasani, John. 1976. George of Trebizond, Leiden-New York.

Platon. 1999a. Timajos. In Platon, Dialogi, Trans. by W. Witwicki, t. 2, Kęty.

Platon. 1999b. Fajdros. In Platon, Dialogi, Trans. by W. Witwicki, t. 2, Kęty.

Pletho, Georgios. 1988. Georgii Gemisti Plethonis Contra Scholarii pro Aristotele Obiectiones. Ed. E. V. Maltese. Leipzig.

Plethon. 1986. De Differentiis. In Woodhouse, Christopher Montague. George Gemistos Plethon. The Last of the Hellenes. Oxford, 192-214.

Plethonis, Georgii Gemisti. 1866. Contra Scholarii defensionem Aristotelis. In Migne, Jacques Paul (ed.). Patrologia Graeca. vol. 160. Paris, 979d-1020b.

Pletone, Giorgio Gemisto. 2001. Delle Differenze fra Platone ed Aristotele. Trans. by M. Neri, Rimini.

Psellos Michał. 1985. Kronika. Trans. by O. Jurewicz, Wrocław.

Siniossoglou, Niketas. 2011. Radical Platonism in Byzantium. Illumination and Utopia in Gemistos Plethon. Cambridge.

Tatakis, Bazyli. 2012. Filozofia bizantyńska. Trans. by S. Tokariew. Kraków.

Taylor, John Wilson. 1921. Georgius Gemistus Pletho's Criticism of Plato and Aristotle. Menasha (Wisconsin).

Wesoły, Marian. 1998. Z Konstantynopola do Florencji, czyli odzyskiwanie greki na Zachodzie. In Eos LXXV, 285-303.

Wesoły, Marian - Jaworska-Wołoszyn Magdalena. 2014. Plethona Zapis praw. In Peitho. Examina Antiqua 1(5), 301-319.

Wesoły, Marian. 2012. Posłowie. In Tatakis, Bazyli, Filozofia bizantyńska. Trans. by S. Tokariew. Kraków, 255-301.

Wesoły, Marian. 2017. Wokół najnowszych badań nad „Metafizyką” Arystotelesa. In Maryniarczyk, Andrzej et al. O metafizyce Arystotelesa. U podstaw filozofowania realistycznego. Lublin, 441-461.

Woodhouse, Christopher Montague. 1986. George Gemistos Plethon. The Last of the Hellenes. Oxford.

Viglas, Katelis. 2010. Zarys historyczny filozofii bizantyjskiej i jej podstawowe zagadnienia. In Peitho. Examina Antiqua 1 (1), 121-144.

Zervas, Theodore. 2018. Plato's Influence on Gerogios Gemistos Plethon's Teachings and Beliefs. http://www.academia.edu/2084630/Plato_s_Influence_on_Gerogios_Gemistos_Plethon_s_ Teachings_and_Beliefs.

Zozulak, Ján. 2016. Byzantská filozofia. Plzeň.

SUMMARY: DE DIFFERENTIIS AND PLETHO'S CRITICISM OF ARISTOTELIAN GOD. Pletho's De Differentiis begins with reflections on Aristotle's God. However, for the Byzantine thinker, all Stagirite's remarks regarding the Supreme Being appear to be fallible. In the light of De Differentiis, Aristotelian God is not the creator of the universe, neither the creator of the beings in it. The author of De Differentiis recognizes Aristotle's 
views as a manifestation of ignorance and misunderstanding of the examined matter, hence he has no chance to compete with his master Plato in the discussion about God. Plethon, by pointing out the differences between Plato and Aristotle, wanted to correct the understanding of their doctrines in the West and to inspire Italian humanists to see that Plato's philosophy deserves more attention because it is actually more in harmony with Christian dogmas than the philosophy of the Stagirite adored in the Western world. On the other hand, apart from the goals set by Plethon in this work, it should be added that his interpretation of Aristotelian God is incompatible with modern research in this field. That is why, apart from presenting Plethon's arguments against Aristotle's concept of God, we also compare his interpretation with more recent findings, according to which Stagirite's Metaphysics does not investigate such fields as theology or ontology, but rather the theory of principles, in the meaning of the first principles and causes.

\author{
Magdalena Jaworska-Wołoszyn, PhD. \\ The Jacob of Paradies Academy \\ Departament of Humanities \\ Teatralna 25 \\ 66-400 Gorzów Wielkopolski \\ Poland \\ margda@yahoo.com
}

